\title{
Overview of Physical Condition of the U-19 Football School Students in Padang Pariaman
}

\author{
Yaslindo*, Teguh Vernanda \\ Sport Education Program \\ Faculty of Sport Science \\ Padang State University \\ Padang, Indonesia \\ jaslindosahoer@gmail.com
}

\begin{abstract}
The purpose of this study was to determine the level of the physical condition of the U-19 students in Padang Pariaman Regency. This type of research is descriptive, involving 20 students. The instruments used were the Yo-Yo Intermittent Recovery Test, T-Test, Linear Sprint Test, Standing Broad Jump Test, Kick Ball Silica Test to measure ankle coordination. The technique of data analysis in this study uses descriptive systematic. The results showed: (1) The ability of Aerobic Endurance is in the "low" classification; (2) Agility ability is in the "poor" classification; (3) Speed ability is in the "low" classification; (4) Ability of Limb Muscle Power in the "sufficient" classification; (5) The Agility Ability of the SSB Midshipman Kapalo Hilalang Students in Padang Pariaman Regency is in the "moderate" classification. (3) Speed ability is in the "low" classification; (4) Ability of Limb Muscle Power in the "sufficient" classification; (5) The Agility Ability of the SSB Midshipman Kapalo Hilalang Students in Padang Pariaman Regency is in the "moderate" classification. (3) Speed ability is in the "low" classification; (4) Ability of Limb Muscle Power in the "sufficient" classification; (5) The Agility Ability of the SSB Midshipman Kapalo Hilalang Students in Padang Pariaman Regency is in the "moderate" classification.
\end{abstract}

Keywords - Physical condition, football, players

\section{INTRODUCTION}

Sport is a part of everyday human activities that are useful for forming physically and mentally healthy. At this time sport provides a positive and tangible impact for the improvement of public health. It also sports played a role in increasing the nation's ability to implement a sustainable development system.

The majority of Indonesian people already realize that health care is absolutely necessary as long as people want to live healthy physically and mentally. This is proven by the race belomba-Indonesian community sports activities, even frequent competitions are the Regional, National and International.

In Indonesia, the existing sports in the community not only for purposes of education, recreation and freshness jasmaniakan but also as a venue for achievement. It is also described in [1]. In Chapter VII, Article 27, paragraph 4 described as follows: "Coaching and sport development achievements implemented by empowering sports clubs, cultivate sports coaching centers, national and regional, and organized a competition in stages and sustainable".
Low sports achievements attained by the athletes Indonesia in general, is one result of a lack of guidance to the athletes, as well as what happens to the sport of football. The lack of guidance not only result in lower physical ability but also have an impact on the ability of football techniques. Of the many sports, one of which is a branch of football proved not only in Indonesia but the people of the world are very fond of football. More than 200 million people worldwide play more than 20 million game of football.

Football is a team sport, each of which consists of 11 players and one of them goalkeepers. Played on a rectangular field with a display size of 100-110 meters wide and 64-75 meters wide as 12 centimeters bounded line and equipped with 2 pieces of net height of 2.44 meters and a width of 7.32 meters. Football game takes place in two rounds, each babaknya 45 minutes with a 15 minute break. The idea of the game of football is "as much as possible to enter the ball into the opposing goal as much as possible and otherwise maintain and prevent the ball into his own goal" [2].

SSB is a container of coaching football early age the most appropriate at this time football schools flooded student. This is a good phenomenon considering the role of schools as the roots of coaching football national football achievements that are able to supply that need the player for the club. The main goal is actually to accommodate SSB and provide opportunities for students to develop their talents. Besides, it also provides a strong base on playing football right includes forming attitudes, personality and behavior. SSB is a heart rate pesepakbolaan coaching youth in Indonesia, [3].

In a football player heading into children experience a variety of stages, like the baby of crawling, standing up to walk. Biologically, physiologically and psychologically children and adolescents in each age level has its own characteristics and traits. Thus, in practice, the coach must adjust to these conditions, for effective training material that is taught to the players.

Youth Football School Kapalo Hilalang who practice football field Kapalo Hilalang Youth Football School is one part of the members of the PSSI Pengcab Padang Pariaman district. In Youth Football School Achievement Kapalo Hilalang minimal achievement in Padang Pariaman regency. If seen from the pattern of the game and individual skills, players are cadets have kulaitas SSB upbringing that sepadang with opponents faced, in fact 
rarely is above the games or opponents. Only the player's output Midshipman SSB exhausted in the third period the game will end. So that this problem has always been a scourge for the team and the players that competed Taruna SSB and opened a gap for the opposing team in order to maximize a player fatigue SSB cadets with an attackattack in the final third of the match time. If this continues then the players will not get a Midshipman SSB maximum performance and will be difficult to rise to a higher level of play with physical ability are increasingly showing exhausted.

The appearance of someone in complete physical tasks he was doing an overview of the quality of the physical elements it has. Elements of physical condition is defined as elements that affect the ability to work. Ability to work is the physical ability to perform physical tasks it faces. Physical ability in the discharge of his duties depends on the quality of accomplishments supporting elements (elements conditions) owned. If each element of the physical condition of a good quality, then for his work would be high.

\section{RESEARCH METHODOLOGY}

This study was a descriptive study. According [4] is a descriptive study research methods that attempted to describe the object or subject under study in accordance with what, with the aim of systematically describe the facts and characteristics of the object studied properly using the test and measurement techniques.

As a research method which we know provides precise lines and propose the conditions are right, the intention is to keep the knowledge attained from one study may have scientific price and high quality. The application of research methods must be the objective at the research so that the results can be in accordance with the expected goals.

Data analysis techniques used for the study is using descriptive statistical formula (tabulation frequency). preparing raw value for each item test by transforming into a T-score, then the result of the default value is matched to the norms of the test item. The results of the data analysis are categorized into five categories: excellent, good, moderate, less and less so.

Based on this type of research is a descriptive study, the data collected will be analyzed using descriptive statistical analysis techniques, by describing the data and present the data in the form of a frequency distribution. To analyze the data unit scores are different, then the first set of raw scores of each of the raw scores [5].

For data that are time converted to the formula:

$t=50-\left(\frac{\mathrm{xi}-\mathrm{m}}{\mathrm{SD}}\right) \mathrm{X} 10$

For data that are frequency or amount, converted to the formula:

$t=50+\left(\frac{\mathrm{xi}-\mathrm{m}}{\mathrm{SD}}\right) \times 10$

Source: Arsil (2016: 23)

The assessment Normative research data refers to the scale of 5A (Arsil, 2016: 22):

$$
\begin{aligned}
& M+(1.5 \times \text { SD })=A \\
& M+(0.5 X \text { SD })=B \\
& M-(0.5 X \text { SD })=C \\
& M-(1.5 X \text { SD })=D
\end{aligned}
$$

With the division in classification:

$$
\begin{aligned}
& \geq \mathrm{A}=\text { Very Good } \\
& \mathrm{A} \mathrm{s} / \mathrm{d} \mathrm{B}=\mathrm{Good} \\
& (\mathrm{B}-1) \mathrm{s} / \mathrm{d} \mathrm{C}=\text { Average } \\
& (\mathrm{C}-1) \mathrm{s} / \mathrm{d} \mathrm{D}=\text { Less } \\
& \leq \mathrm{D}=\text { Less than Once }
\end{aligned}
$$

The formula used to calculate the percentages are as follows:

$$
P=\frac{f}{n} \times 100 \%
$$

Information :

$\mathrm{P}=$ Percentage

$\mathrm{F}=$ Frequency of respondents (Score obtained)

$\mathrm{N}=$ Number of Respondents

\section{Aerobic Endurance}

\section{RESULTS AND DISCUSSION}

Based on the results of the test and measurement of aerobic endurance Students SSB Taruna Kapalo Hilalang

\begin{tabular}{|c|c|c|c|}
\hline Distance & Classification & $\mathbf{F}$ & Percentage \\
\hline$\geq 3000$ & Excellent & 1 & $5 \%$ \\
\hline $2760-3000$ & Very Good & 1 & $5 \%$ \\
\hline $2600-2720$ & Good & 2 & $10 \%$ \\
\hline $2200-2560$ & moderate & 2 & $10 \%$ \\
\hline $1800-2160$ & Low & 6 & $30 \%$ \\
\hline$\leq 1800$ & Poor & 8 & $40 \%$ \\
\hline \multicolumn{2}{|c|}{ Total } & 20 & $100 \%$ \\
\hline
\end{tabular}
Padang Pariaman district that has been done, the level of aerobic endurance Students SSB Taruna Kapalo Hilalang Padang Pariaman district to get the lowest score of 1000, while the highest value of 3040. As for the classification level of aerobic endurance Students Taruna SSB Kapalo Hilalang Padang Pariaman district can be seen in the table below:

Table 1. Endurance Aerobic Capability Level Students SSB Taruna Kapalo Hilalang Padang Pariaman

From the table above we can see the percentage level of aerobic endurance capability Students SSB Taruna Kapalo Hilalang Padang Pariaman district. There is a 5\% Students SSB Taruna Kapalo Hilalang Padang Pariaman district were on the classification of "excellent", 5\% in the classification of "very good", $10 \%$ are in the classification of "good" $10 \%$ are in the classification of "moderate", $30 \%$ are in the classification "low", and $40 \%$ are in the classification of "poor". The results of the percentage level of aerobic endurance capability Students SSB Taruna Kapalo Hilalang Padang Pariaman district can be seen in the histogram below: 


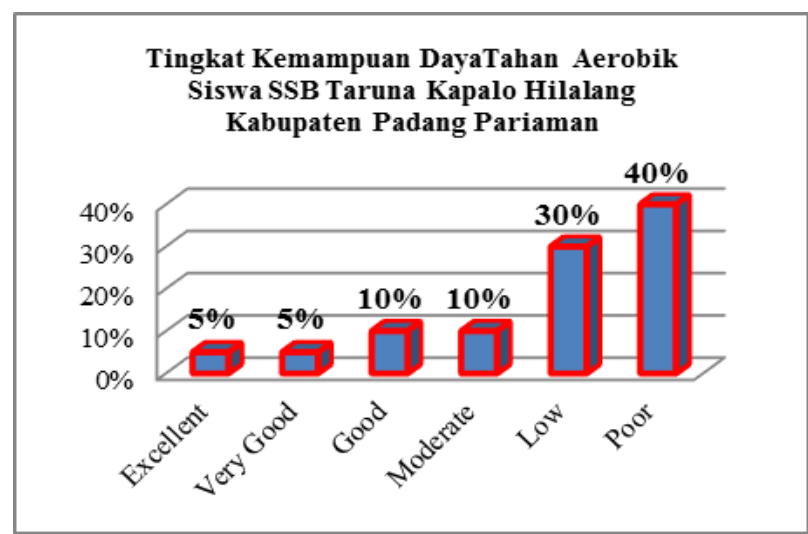

Figure 1. Ability Levels histogram Students Aerobic Endurance SSB Taruna Kapalo Hilalang Padang Pariaman

Researchers can thus conclude that the ability of Aerobic Endurance Students SSB Taruna Kapalo Hilalang Padang Pariaman district were on the classification of "LOW" with an average of "2034".

Agility

Based on the results of the test and measurement agility Students SSB Taruna Kapalo Hilalang Padang Pariaman district that has been done, the level of agility Students SSB Taruna Kapalo Hilalang Padang Pariaman get the lowest score of 14:22, while the highest value of 9:12. As for the classification level of agility Students SSB Taruna Kapalo Hilalang Padang Pariaman district can be seen in the table below:

Tabel 2. Agility level Students SSB Taruna Kapalo Hilalang Padang Pariaman

\begin{tabular}{|c|c|c|c|}
\hline Time (Seconds) & Classification & $\mathbf{F}$ & Percentage \\
\hline$\leq 9.5$ & Excellent & 3 & $15 \%$ \\
\hline $10.5-9.5$ & Good & 4 & $20 \%$ \\
\hline $11.5-10.5$ & Average & 3 & $15 \%$ \\
\hline$\geq 11.5$ & Poor & 10 & $50 \%$ \\
\hline \multicolumn{2}{|c|}{ Total } & 20 & $100 \%$ \\
\hline
\end{tabular}

From the table above we can see the percentage level of agility capabilities Students SSB Taruna Kapalo Hilalang Padang Pariaman district. There is a $15 \%$ Students SSB Taruna Kapalo Hilalang Padang Pariaman district were on the classification of "excellent", $20 \%$ are in the classification of "good", $15 \%$ are in the classification of "average", and $50 \%$ are in the classification of "poor". The results of the percentage level of agility capabilities Students SSB Taruna Kapalo Hilalang Padang Pariaman district can be seen in the histogram below:

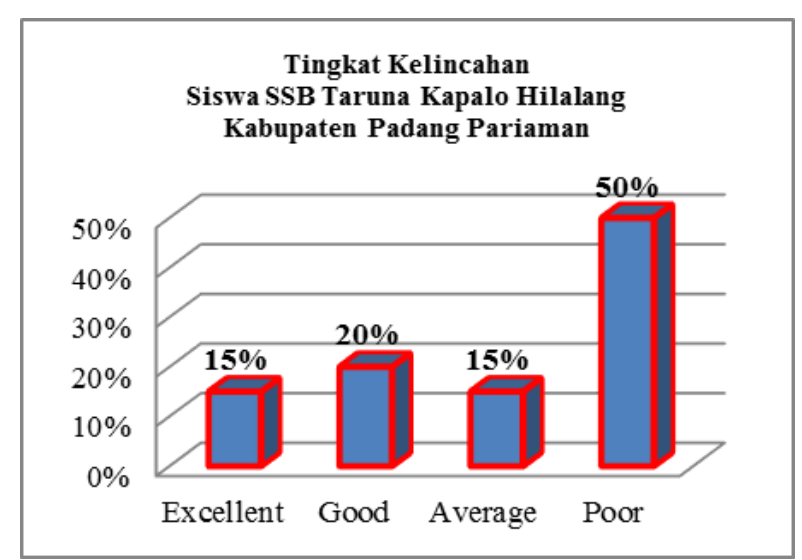

Figure 2. Students Agility Levels histogram SSB Taruna Kapalo Hilalang Padang Pariaman

Thus it can be concluded that the ability of researchers Students SSB Taruna Agility Kapalo Hilalang Padang Pariaman district were on the classification of "POOR" the average "11.67".

\section{Speed}

Based on the results of the test and measurement speed of Students SSB Taruna Kapalo Hilalang Padang Pariaman district that has been done, the pace Students SSB Taruna Kapalo Hilalang Padang Pariaman get the lowest score of 4.70 while the highest value of 4:09. The speed level classification Students SSB Taruna Kapalo Hilalang Padang Pariaman district can be seen in the table below:

Tabel 3. Rate-Taruna Students SSB Kapalo Hilalang Padang Pariaman

\begin{tabular}{|c|c|c|c|}
\hline $\begin{array}{c}\text { time } \\
\text { (Seconds) }\end{array}$ & Classification & $\mathbf{F}$ & Percentage \\
\hline$\leq 4: 10$ & Excellent & 1 & $5 \%$ \\
\hline $4: 10$ to $4: 20$ & Very Good & 1 & $5 \%$ \\
\hline $4: 20$ to $4: 30$ & Good & 2 & $10 \%$ \\
\hline $4: 30$ to $4: 40$ & moderate & 4 & $20 \%$ \\
\hline $4: 40$ to $4: 50$ & low & 7 & $35 \%$ \\
\hline$\geq 4: 50$ & Poor & 5 & $25 \%$ \\
\hline \multicolumn{2}{|c|}{ Total } & 20 & $100 \%$ \\
\hline
\end{tabular}

From the table above we can see the percentage rate at Taruna Kapalo Students SSB Hilalang Padang Pariaman district. There is a 5\% Students SSB Taruna Kapalo Hilalang Padang Pariaman district were on the classification of "excellent", 5\% in the classification of "very good", $10 \%$ are in the classification of "good", $20 \%$ are in the classification of "moderate", 35\% are in classification of "low" and another $25 \%$ are in the classification of "poor".

The percentage of students SSB Taruna speed level Kapalo Hilalang Padang Pariaman district can be seen in the histogram below: 


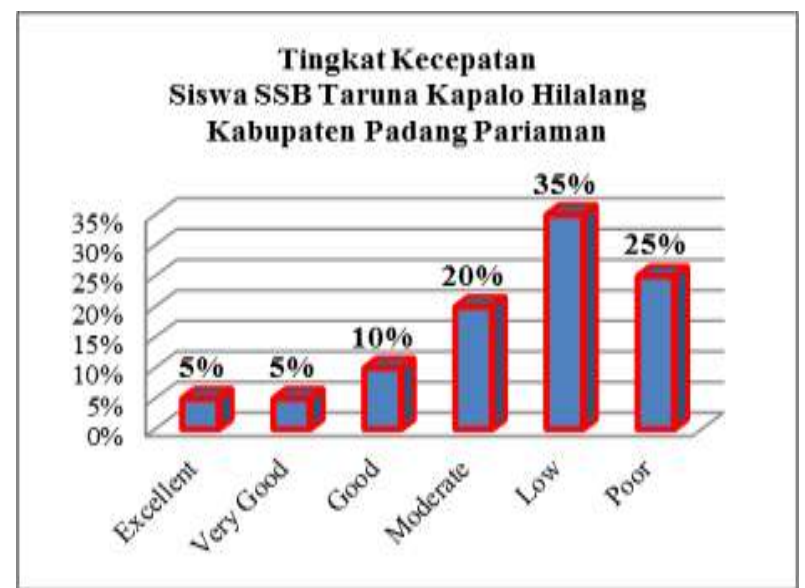

Figure 3. Histograms Rate-Taruna Students SSB Kapalo Hilalang Padang Pariaman

Researchers can thus conclude that the level of SSB Youth Student Speed Kapalo Hilalang Padang Pariaman district were on the classification of "LOW" with the average "4:44".

\section{Explosive power Leg Muscles}

Based on the results of the test and measurement of leg muscle explosive power Kapalo Hilalang Students SSB Taruna Padang Pariaman district that has been done, the level of ability of leg muscle explosive power Kapalo Hilalang Students SSB Taruna Padang Pariaman district to get the lowest score of 65, while the highest value of 101 . As for the classification level of ability Students leg muscle explosive power SSB Taruna Kapalo Hilalang Padang Pariaman district can be seen in the table below:

Tabel 4. Ability level Limb Muscle Power Burst Students SSB Taruna Kapalo Hilalang Padang Pariaman

\begin{tabular}{|c|c|c|c|}
\hline Distance & \multirow{2}{*}{ Classification } & \multirow{2}{*}{$\mathbf{F}$} & \multirow{2}{*}{ Percentage } \\
\hline (inch) & & & \\
\hline $96-109$ & Very well & 5 & $25 \%$ \\
\hline $91-95$ & Well & 6 & $30 \%$ \\
\hline $85-90$ & Enough & 5 & $25 \%$ \\
\hline $79-84$ & Less & 3 & $15 \%$ \\
\hline $63-78$ & Less than Once & 1 & $5 \%$ \\
\hline \multicolumn{2}{|c|}{ Total } & 20 & $100 \%$ \\
\hline
\end{tabular}

From the table above we can see the percentage level of leg muscle explosive power capability Students SSB Taruna Kapalo Hilalang Padang Pariaman district. There is a 25\% Students SSB Taruna Kapalo Hilalang Padang Pariaman district were on the classification of "excellent", $30 \%$ are in the classification of "good", $25 \%$ are in the classification of "enough", $15 \%$ are in the classification of "less", and 5\% are on the classification of "less so". The percentage of leg muscle explosive power levels Students SSB Taruna Kapalo Hilalang Padang Pariaman district can be seen in the histogram below:

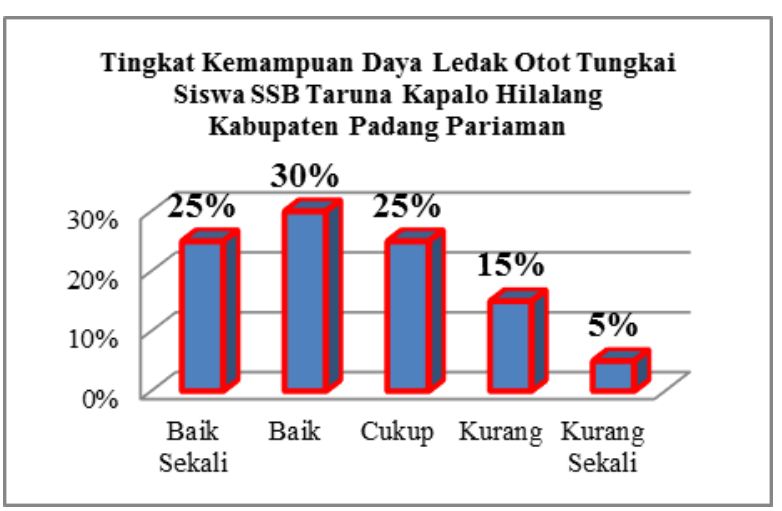

Figure 4. Power Capability Levels histogram Explosive Leg Muscles Students SSB Taruna Kapalo Hilalang Padang Pariaman

Thus it can be concluded that the ability of researchers Explosive Muscle Power Limbs Students SSB Taruna Kapalo Hilalang Padang Pariaman district were on the classification of "ENOUGH" with an average of "90".

\section{Coordination}

Based on the results of tests and measurements of Students SSB Taruna Kapalo coordination Hilalang Padang Pariaman district that has been done, the level of coordination Students SSB Taruna Kapalo Hilalang Padang Pariaman district to get the lowest score of 11 , while the highest value of 22. As for the classification level of coordination Students SSB Taruna Kapalo Hilalang Padang District Pariaman can be seen in the table below:

Tabel 5. Students Coordination level Kapalo Hilalang SSB Taruna Padang Pariaman

\begin{tabular}{|c|c|c|c|}
\hline Supreme & Classification & $\mathbf{F}$ & Percentage \\
\hline$\geq 20$ & Very well & 1 & 5 \\
\hline $17-20$ & Well & 6 & 29 \\
\hline $15-16$ & moderate & 7 & 33 \\
\hline $12-14$ & Less & 5 & 24 \\
\hline$\leq 12$ & Less than Once & 2 & 10 \\
\hline \multicolumn{2}{|r|}{ Total } & 21 & 100 \\
\hline
\end{tabular}

From the table above we can see the percentage level of coordination Students SSB Taruna Kapalo Hilalang Padang Pariaman district. There is a 5\% Students SSB Taruna Kapalo Hilalang Padang Pariaman district were on the classification of "excellent", 29\% are in the classification of "good", $33 \%$ are in the classification of "medium", 24\% are in the classification of "less", and $10 \%$ were on the classification of "less so". The results of the percentage level of coordination Students SSB Taruna Kapalo Hilalang Padang Pariaman district can be seen in the histogram below: 


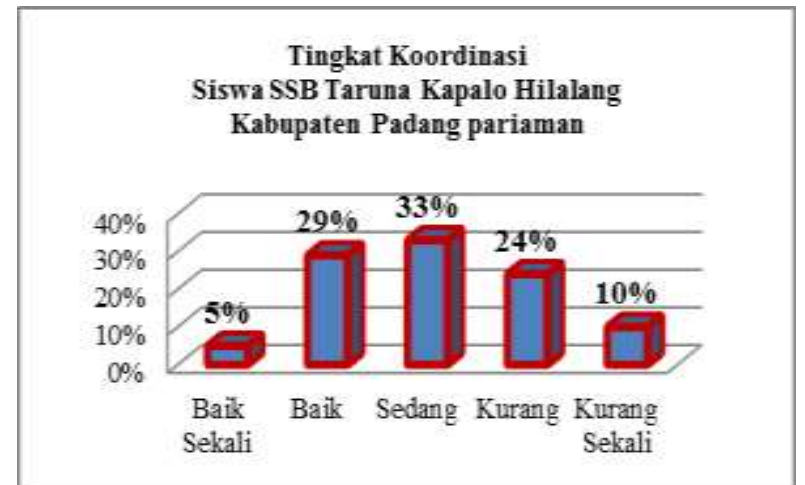

Figure 5. Students Coordination Levels histogram SSB Taruna Kapalo Hilalang Padang Pariaman

Thus it can be concluded that the level of agility researchers Students SSB Taruna Kapalo Hilalang Padang Pariaman district were on the classification of "MEDIUM" with an average of "16".

\section{Physical condition}

Based on the results of the test and measurement of Physical Condition of Students SSB Taruna Kapalo Hilalang Padang Pariaman district that has been done, the level of coordination Students SSB Taruna Kapalo Hilalang Padang Pariaman get the lowest score of 197.76 while the highest value of 323.35. The classification of the level of coordination Students SSB Taruna Kapalo Hilalang Padang Pariaman district can be seen in the table below:

Tabel 6. Students Coordination level Kapalo Hilalang SSB Taruna Padang Pariaman

\begin{tabular}{|c|c|c|c|}
\hline $\begin{array}{c}\text { total } \\
\text { T-Skore }\end{array}$ & Classification & $\mathbf{F}$ & Percentage \\
\hline$\geq 302.84$ & Very well & 1 & 5 \\
\hline $268.12-302.84$ & Well & 4 & 20 \\
\hline $233.39-268.11$ & moderate & 7 & 35 \\
\hline $198.67-233.38$ & Less & 7 & 35 \\
\hline$\leq 198.67$ & Less than Once & 1 & 5 \\
\hline \multicolumn{2}{|c|}{ Total } & 20 & 100 \\
\hline
\end{tabular}

From the table above we can see the percentage level of coordination Students SSB Taruna Kapalo Hilalang Padang Pariaman district. There is a 5\% Students SSB Taruna Kapalo Hilalang Padang Pariaman district were on the classification of "excellent", 20\% are in the classification of "good", 35\% are in the classification of "medium", 35\% are in the classification of "less", and 5\% are on the classification of "less so". Results of Student Physical Condition level percentage SSB Taruna Kapalo Hilalang Padang Pariaman district can be seen in the histogram below:

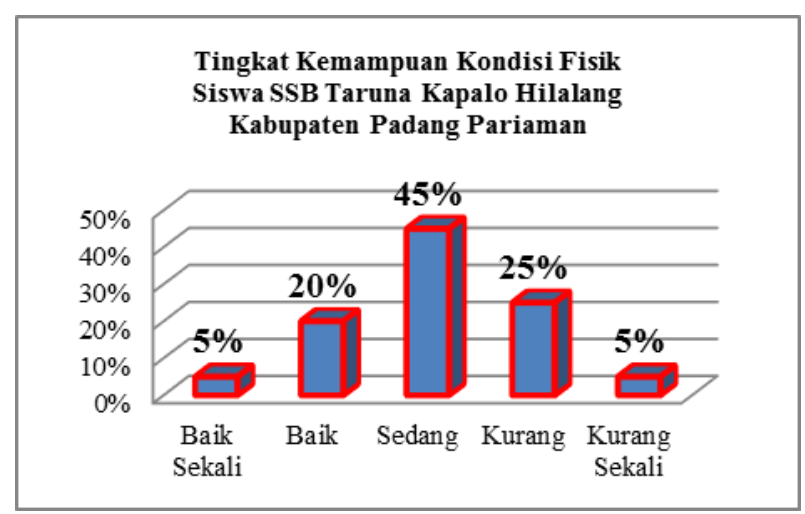

Figure 6. Students Physical Condition Level Histogram SSB Taruna Kapalo Hilalang Padang Pariaman

Researchers can thus conclude that the level of SSB Youth Student Physical Condition Kapalo Hilalang Padang Pariaman district were on the classification of "MEDIUM" to the average "250.22".

\section{CONCLUSION}

Based on data analysis and discussion, as well as data processing that has been done, the level of SSB Youth Student Physical Condition Kapalo Hilalang Padang Pariaman can be concluded that: (1) The ability of Aerobic Endurance currently on the classification of "low"; (2) Ability Agility is a classification of "poor"; (3) Free Ability currently on the classification of "low"; (4) Ability Explosive Muscle Power Limbs owned Kapalo Students SSB Taruna Hilalang Padang Pariaman district were on the classification of "enough"; (5) Ability Agility owned Kapalo Students SSB Taruna Hilalang Padang Pariaman district were on the classification of "medium".

\section{REFERENCES}

[1] Undang-Undang Republik Indonesia No. 3 (2005). Sistem Keolahragaan Nasional. 2005.pp. 10-24

[2] Yulifri. "Sepakbola Dasar". Padang : Universitas Negeri Padang. 2012.pp.55-65.

[3] SP . Ardias. "Pemetaan Manajemen Pembinaan Sekolah Sepak Bola (SSB) Yang Berada Dibawah Naungan IKA SSB (Ikatan Keluarga Sekolah Sepak Bola) Di Kabupaten Bantul”. Yogyakarta : Skripsi FIK Universitas Negeri Yogyakarta. 2015. pp. 34-46

[4] A, Suharsimi. "Prosedur Penelitian". Jakarta: Rineka Cipta. 2002.pp.13-34.

[5] Arsil. "Evaluasi Pendidikan Jasmani dan Olahraga". Padang : Universitas Negeri Padang. 2015.pp.55.76. 